\title{
GEORGE WAREING ORMEROD, M.A., F.G.S.
}

Among the losses recently sustained by geological science, we have to record that of $\mathrm{Mr}$. G. W. Ormerod, who died at Teignmouth on January 6th, aged 82. He was a son of the late George Ormerod of Tyldersley House, Lancaster, and Sedbury Park, Gloucester, well known as the author of "The History of Cheshire." The Ormerods were a family which had been connected with Ormerod Hall, near Burnley, in Lancashire, since the time of Edward III.

G. W. Ormerod, after taking his degree at Oxford, practised for some years in the law at Manchester; he subsequently resided at Chagford on the borders of Dartmoor, and for the last twenty years at Teignmouth. To the country in which he resided he devoted most of his attention as a geologist. His papers included the following: an Outline of the principal Geological Features of the Salt-field of Cheshire and the adjoining districts; on the "Waterstone Beds" of the Keuper; on some Veins of Granite in the Carbonaceons Rocks on the North and East of Devon and East of Dartmoor; Geology of the upper part of the valley of the Teign ; on the Structure of the Granite of Dartmoor; and papers on the New Red rocks of the neighbourhood of Teignmouth. T'o geologists he was perhaps best known as the compiler of the Classified Index to the T'ransactions, Proceedings, and Quarterly Journal of the Geological Society, of which the third supplement (up to 1889) was published last year. He was one of the original members of the Devonshire Association, and one of the founders of the Teign Naturalists' Field Club, of which for many years he was Secretary.

\section{WILLIAM DAVIES, F.G.S.}

WE regret to record the death of $\mathrm{Mr}$. William Davies, F.G.S., for forty-four years connected with the Geological Department of the British Museum. Mr. Davies was born at Holywell, Flintshire, in 1814, and entered the Museum on 19th Dec. 1843. He had already studied Botany, and had made a good Hortus siccus of British plants. Under Mr. Charles König, he devoted himself to Mineralogy, and soon became an excellent eye-mineralogist. He also worked at the fossil fishes in the Museum, many of which he afterwards described in this MAGAZiNe. He devoted many years of patient study to the fossil Vertebrates, but his knowledge was generously given to others as soon as solicited. With Sir Antonio Brady he formed a fine collection of the Mammalian-remains from the Thames-Valley Brickearth, which he described and catalogued. The Geological Society of London, in 1873, awarded Mr. Davies the first Murchison Medal; and in 1877 elected him a Fellow of the Society, the Council presenting him with the Life Fellowship.

In $1875 \mathrm{Mr}$. Davies was made an Assistant, and in 1880 promoted to the First Class, in recognition of his valuable services. He took a very active part in the removal and re-arrangement of the Geological Collections at Cromwell Road, from 1880 to 1887, when he retired on a pension. He died on the 13th February last, warmly esteemed and deeply regretted by all who knew him.

$A$ list of his papers will appear in next month's issue. - H. W. 
Geol. Mag. I89I.

Decade III. Vol. ViII. Pl. IV.
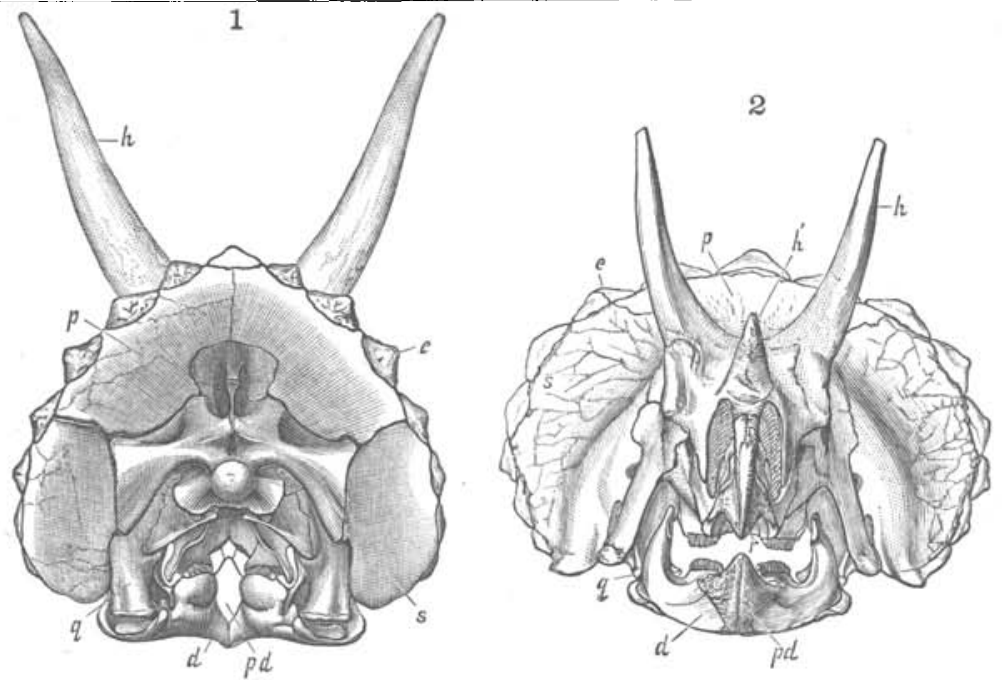

3
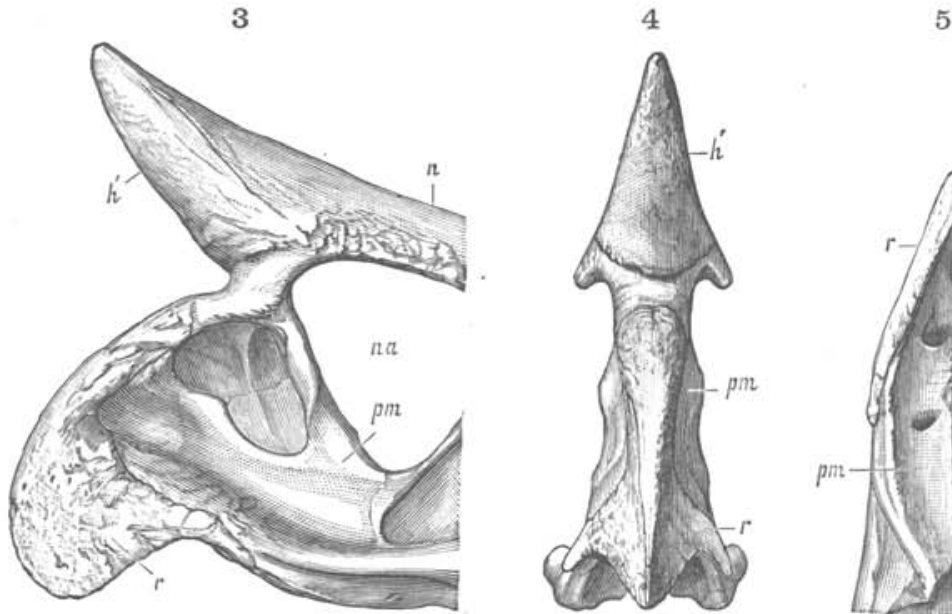

5

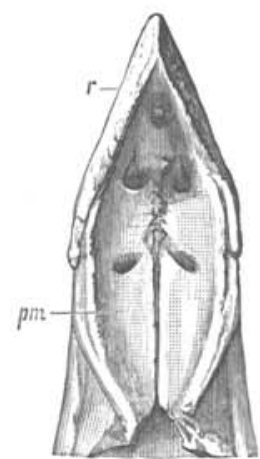

6

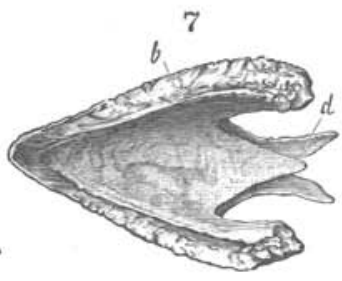

8
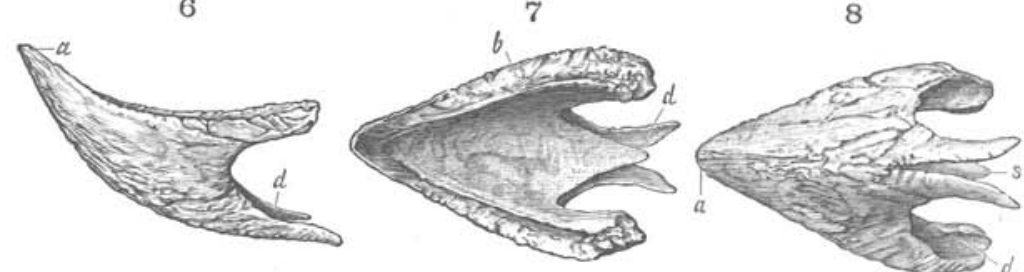

THE GIGANTIC CERATOPSIDE.

To illustrate Prof. O. C. MARsh's second paper on Triccratops, from the Upper Cretaceous of North America (May, I89r); see aIso previous paper in Grol. Mig. Decade III. Vol. VII. Pl. I. pp. I-5, 1800 . 